\title{
The Effects of Corporate Social Responsibility on Customers' Loyalty in Lao PDR
}

\author{
Saykham Phongsavath ${ }^{1} \quad$ Somchith Sompaseuth ${ }^{1,2} \quad$ Sorphasith Xaisongkham ${ }^{2 *}$ \\ Phoneaphay Xayavong ${ }^{1}$ Venepheth Sayavong ${ }^{1} \quad$ Vadsana Somphon $^{1}$ \\ 1. Faculty of Economics and Business Management, National University of Laos P.O. Box 7322, Xaythany, \\ Vientiane Capital, Lao PDR \\ 2. School of Business, Zhengzhou University 100 Science Avenue, Zhengzhou, Henan 450001, China \\ *E-mail: Sorphasithxsk@yahoo.com
}

\begin{abstract}
Corporate social responsibility (CSR) has become an essential mainstream in research circles at present, especially for organizational business management and has been adopted as long-term strategic plans. It plays a crucial role in espousing robust business operation, moderating the harmful negative effect of environmental degradation and being an integral aspect in promoting social and community activities as well as enhancing people's quality of life. Nevertheless, very few empirical studies focused on the effects of CSR on customers' loyalty in a telecommunication sector and none of empirical evidence have investigated in case of Lao PDR. Hence, this paper empirically investigates on the effects of CSR on customers' loyalty in Lao PDR by employing multiple linear regression model to uncover the relationship between an explained variable and a set of regressor in the estimated model. Empirical findings substantiated a positive effect and statistical significance of philanthropic, environmental and legal responsibility on customers' loyalty, whilst legal responsibility has a weak positive influence on an explained variable and the outcomes also found that ethical behavior is positively affected but statistical insignificance on customers' loyalty. In addition, the paper strongly averred that CSR contributes to increase customers' loyalty, investments in CSR activities helps to reach sustainable business development goals and mitigate the potential adverse impact caused from business operation. More importantly, policy implications provide crucial insights and the fundamental role of CSR initiatives in establishing the innovative marketing strategy, contemporary business management and their survival in the era of high competition.
\end{abstract}

Keywords: CSR, Customers' Loyalty, Multiple Regression Model, Lao Telecom, Lao PDR

DOI: $10.7176 / \mathrm{EJBM} / 13-12-01$

Publication date:June $30^{\text {th }} 2021$

\section{Introduction}

Corporate Social Responsibility (Hereafter is so-called CSR) has become a research mainstream that pays enormous interests by numerous scholars in the context of business organization and other social researches at present. CSRs is considered as an essential strand involving between companies and their stakeholders (ServeraFrancés \& Piqueras-Tomás, 2019) and is a key element to achieve the sustainable business development (Behringer, 2016), which firms are encouraged to participate in CSR activities in order to demonstrate the high accountability on community and society as well as reducing the potential negative impacts of their business operation. Many companies have endeavored in seeking distinctive strategies to better brand image together with maintaining their customer loyalty (Kim \& Kim, 2016) and CSR is now deemed as a pivotal weapon of current marketing strategy for companies. The concept of CSR components has extensively discussed in seminal studies, which put forward divergent notions (Dahlsrud, 2008; Galbreath \& Shum, 2012; Slavova, 2017; Vilanova et al., 2008) and has become one of the most important challenges in addressing environmental issues and attaining the green-sustainable development goals up to the present.

Similarly, the effects of CSR on customers' loyalty have long been discussed and debated in literature reviews as they recommended controversial problems and some shortcomings like (Mohammed \& Rashid, 2018) suggested the need to affirm and test for service and manufacturing sectors (Irshad et al., 2017), while it would be interesting to investigate diverse industries and cultures, and to apply the outcomes of current research by augmenting the models in order to prove other disparate findings (Kim \& Kim, 2016). Other studies argued and put forward in examining the impacts of CSR and processing fluency on customers' feedback in the real service sectors, testing other components of CSR and their relationships with constructs (Zhang \& Mattila, 2015, Andre HJ Jeurissen, 2017); there is also the need to consider the relative significance of various comparison standards for customers and longitudinal research (Chung et al., 2015) specifically how comparison standards change overtime (Wong \& Sohal, 2003). Furthermore, researchers should take into consideration the big proxy samples from the large customer population and test significant difference between perceptions in CSR and demographical variables such as educational level, sex, age and so on (Arjoon \& Rambocas, 2011). Nevertheless, the effects of CSR on customers' loyalty have still regarded as debatable notions in current 
research circles and other social business organizations.

CSR plays an essential role in promoting public image, brand awareness, marketing management system, competitive advantage over rivals, customers' satisfaction and attaining sustainable business development. Nowadays, many companies are adopting CSR activities as a pivotal marketing strategy to penetrate the broader customer targets and dominate over their competitors in the marketplace. To this end, by realizing the crucial problems and existing gaps mentioned above. Consequently, the objectives of this seminal research are to delve the effects of corporate social responsibility on customers' loyalty in Lao PDR by extending and fulfilling the insoluble problems as well as the remaining gaps deriving from the previous studies (Mohammed \& Rashid, 2018; Zhang \& Mattila, 2015, Andre HJ Jeurissen, 2017). Specifically, our research accentuates on the analysis of service sector by selecting Lao Telecom, which is a leading telecommunication company (The epitome company of CSR activities in Lao PDR) and will focus on the side of customers' attitude of CSR influencing on their loyalty to fulfil some defects recommended from preceding paper (Arjoon \& Rambocas, 2011). In this sense, we selected Lao Telecom as a case study because this company has been an epitome firm that prodigiously participate in contributing CSR initiatives notably the helps in social and community development, educational scholarship for abject people and excellent students, impacts of natural disastrous crisis and outbreaks (Covid-19), environmental protections and social important activities, which has sponsored and donated more than 1.4 billion KIP during 2017-2020.

Moreover, we can notice that few studies have focused on service sectors as well as the telecommunication service sector and the lack of empirical research on the effects of CSR on customers' loyalty in case of Lao PDR. We also ponder to test whether there is a statistically significant difference between the considered demographical factors towards customers' loyalty, which have not utilized in previous studies. Therefore, this paper would be one of the paramount pioneering research in identifying and capturing the skeptical question on how CSR activities affecting on customers' loyalty?; does CSR activities actually increase customers' or brand loyalty? and what is the major components of CSR activities to implant and rise the customers' loyalty?. The paper will also uncover thorough insights and demonstrate the essential CSR strategy to penetrate and implant more customers' loyalty and will provide some beneficial directions in order to establish a robust competitive advantage strategy through CSR activities of Lao Telecom company in Lao PDR. The remaining section of the paper is organized as follows: Section 2 describes the reviews of literature and testable hypothesis. Section 3 briefly explains research methodology. Section 4 demonstrates the outcomes of empirical research. Finally, Section 5 epitomizes the results of empirical study including research limitations and future directions respectively.

\section{Reviews of Literature and Testable Hypothesis CSR and Customers' Loyalty}

Many studies have averred the existence for effects of CSR and service quality on customers' brand loyalty and its effects are being discussed in current researches. The definition of CSR was extensively discussed in previous papers (Dahlsrud, 2008), which CSR can be defined in disparate perspectives. In general, it refers to an action that a company is committed to take the societal obligations (Kim \& Kim, 2016) particularly many firms are encouraged to participate in social and community activities. The most fundamental components of CSR activities in general are viewed from four dimension including economic, ethical, philanthropic and legal dimension (Galbreath \& Shum, 2012), while other studies put forward the different components of CSR (See in Dahlsrud, 2008; Slavova, 2017; Vilanova et al., 2008). Nevertheless, (Raza et al., 2020) mentioned that CSR has become a multidimensional informative constructs that directly and indirectly impacts customers' loyalty; it plays a pivotal role in increasing and improving the better customers' loyalty, company's beneficial image (Diehl et al., 2016) and long-term business strategy. In addition, CSR has been used as an effective marketing strategy to acquire customer loyalty (Li et al., 2019) and becomes a competitive edge for all of companies in disparate industrial sectors (Castro-González et al., 2019).

A lot of business organizations have endeavored at all costs in adjusting the appropriate marketing strategy as well as creating the brand image and customers' satisfaction in order to improve and promote customers' loyalty. Therein, the concepts of customers' loyalty were extensively developed and theorized in the preceding studies including the possible burgeoning papers. On balance, customers' loyalty refers to when customers repeatedly and frequently purchase the same brand products/services from company (Tellis, 1988), albeit obtaining situational effects, marketing efforts and various persuasions from other company (Oliver, 1999); it is also a vital component in promoting and developing a sustainable competitive edge (Dick \& Basu, 1994) and generating long term profitability for company as well. In this paper, customers' loyalty refers to when customer frequently adheres in the use of the same-brand products/service, despite other company offer and suggest the better products/services. However, numerous studies found and affirmed a positive effect of CSR on customers' loyalty and so on. 


\section{The Effects of Environmental Responsibility on Customers' Loyalty}

Technical speaking, environmental responsibility is an essential aspect in generating and improving customers' loyalty as well as there is a relationship between two variables. Empirical studies asserted a positive impact of environmental factor on customers' loyalty (Moisescu \& Gică, 2020) and also suggested the need to consider other service sectors from developing countries. By way of contrast, another scholar discovered that environmental responsibility was negatively influenced but not statistically significant on customers' loyalty (Dimitriadis \& Zilakaki, 2019); the paper also recommended to explore for disparate sectors; while there was a strong influence for the impact of CSR components on Chinese customers' loyalty (Liu et al., 2019); customer environmental satisfactions and environmental friendliness of the company has a statistical significance and positive impact on customer loyalty (Mohd Suki, 2015). Similarly, CSR activities in term of environmental responsibility plays a major part in pushing the long-term sustainable business performance and being a key to build customers' consciousness on products/services namely service sector, which environmental responsibility can increase more and more customers' loyalty through corporate environmental activities, a cleaner environment, environmental stewardship involving in business operation and taking initiative in reducing the environmental degradation and so on. Nevertheless, the skeptical question on how environmental responsibility influences on customers' loyalty are treated as the unclear outcomes, insoluble arguments and few empirical studies have accentuated on it. For this reason, it is allowed us to construct a first testable assumption as followings:

$\mathrm{H}_{1}$ : Environmental responsibility is positively affected and statistically significant on customers' loyalty.

\section{The Effects of Ethical Responsibility on Customers' Loyalty}

As a rule, business ethics of the company conduces to espouse and aggrandize customers' loyalty in service sector as well as telecommunication sector. To become the winner and market leader, many companies must pay special attentions in addressing the issues of ethical behaviors in order to achieve in establishing and binding their customers' loyalty. Likewise, some studies substantiated a positive relationship and statistical significance between ethical responsibility and customers' loyalty (Arjoon \& Rambocas, 2011); the results also advanced that it was essential to take into account for the broader customer population, and the need to identify whether there is a statistically significant difference between/among respondents' demography (particularly: age, ethnicity, computer literacy and educational level respectively) towards components of CSR and customers' loyalty; while (Islam et al., 2021) took exception that the telecom sectors should spend in the ethical initiatives because customers prefer to support those organizations that are ethically responsible; and ethical attitude of society on firms has considered as a key element to construct a reliable relationship (Swaen \& Chumpitaz, 2008). Business operation in the ethical ways will affect the overall image of company and rise customers' loyalty (Zhang et al., 2015). However, previous researchers have left significant gaps, while these are necessary to uncover and disentangle in case of service sectors as well as telecommunication sector (Lao Telecom company) in Lao PDR. For this purpose, we construct the testable assumptions as below:

$\mathrm{H}_{2}$ : Ethical responsibility has a statistical significance and positive influence on customers' loyalty.

$\mathrm{H}_{3}$ : There is a statistically significant difference between males' and females' attitude towards customers' loyalty.

$\mathrm{H}_{4}$ : There is a statistically significant difference between customers' perception living in Vientiane capital and other province towards customers' loyalty.

$\mathrm{H}_{5}$ : There is a statistically significant difference among respondents' monthly income level towards customers' loyalty.

$\mathrm{H}_{6}$ : There is a statistically significant difference among respondents' duration of service use towards customers' loyalty.

\section{The Effects of Legal Responsibility on Customers' Loyalty}

Legal responsibility is an integral part of CSR influencing on business operation, which companies/organizations should implement business under the rules, laws and relevant regulations officially promulgated by central and local government in each period (Irshad et al., 2017). Likewise, it is also vital to comply with the ad hoc regulations due to divergent sectors/industries have adopted distinctive rules; successful organizations can define as the one that fulfil their legal obligation and provide goods and various services at least corresponding with the minimal legal requirements (Galbreath \& Shum, 2012). Many studies confirmed the positive effect and statistical significance of legal responsibility variable on customer's loyalty (Irshad et al., 2017; Nyambura., 2018; Ogetii Marita \& Nyatichi Marita, 2019) and suggested further research on service sectors. In addition, legal responsibility also contributes to improve and enhance the relationship with customers that engenders to accrue customers' loyalty at last. By realizing the importance of existing holes deriving from previous literatures and none of researchers have investigated in case of Lao PDR. Consequently, this paper has postulated as followings: $\mathrm{H}_{7}$ : Legal responsibility is statistically significant and positive impact on customers' loyalty. 


\section{The Effects of Philanthropic Responsibility on Customers' Loyalty}

Philanthropic responsibility plays a vital role in creating good image, trust and business reputation, which conduces to increase and lift customers' loyalty through making the good and close relationship with customers; helping the publics, abject and disadvantaged people by enhancing their quality of life; the more companies take part in philanthropic activities, the more they can penetrate to vaster target customers and increase customers' loyalty. In general, philanthropic action has been used as a contemporary marketing strategy that many companies have adopted in the era of current competition in order to take competitive advantage of contenders as well as scratching more market share in the same industry. Many organizations should encourage in various activities of local community, educational institutions and other foundations in order to achieve their long-term accomplished business. According to (Chrisjatmiko \& Margareth, 2018) found that there was a statistical significance and positive influence of philanthropic responsibility on customers' loyalty through customer purchase behavior, whilst another paper also reassured overall components of CSR are positively affected and statistically significant on customers' loyalty (Irshad et al., 2017). Nevertheless, based on the important role of Lao Telecom company that puts numerous efforts on social and community activities in Lao PDR and only few papers have particularly focused on the effects of philanthropic responsibility on customers' loyalty. Thus, we have proposed the following postulation.

$\mathrm{H}_{8}$ : Philanthropic responsibility has a positive effect and statistical significance on customers' loyalty.

\section{Research Methodology}

\section{Measurements and Questionnaire Constructions}

To achieve the goals of this research as well as proving the aforesaid hypotheses, we have adopted quantitative research based on questionaries (Primary data), which all the measurement items of CSR components were adjusted from past literatures. We gauged all items by adopting a five-point Likert scale from 1 to 5 (1=Strongly Disagree, $5=$ Strongly Agree). Therein, CSR components such as ethical, legal, philanthropic and environmental responsibility were adapted and developed from seminal studies (Dahlsrud, 2008; Galbreath \& Shum, 2012; Kim \& Kim, 2016; Maignan et al., 2005; Pérez \& Bosque, 2014) and all the items were adjusted to correspond with actual condition in case of telecommunication sector (Service sector) as well as Lao Telecom company in Lao PDR.

\section{Data Collection}

This study has collected data and various information from all the respondents who are currently using Lao Telecom company's service countrywide, which the questionnaire was demonstrated thorough descriptions to circumvent misunderstanding and biased information obtained from respondents. We explicitly stated in the introduction of questionnaire that this survey form has merely been constructed for the ad hoc academic purposes, all the data and information would be strictly anonymous, kept confidential and would not affect respondents anymore. Likewise, we also expounded there was no right or wrong from their responses but we were merely interested in customers' perception on CSR and loyalty. To test the aforesaid assumptions above, we implemented an online survey through social medias to gather data and information from Lao citizens nationwide and we finally obtained complete samples of 427 questionnaire from customers of Lao Telecom company in order to investigate the effects of CSR on customers' loyalty in service sector in Lao PDR.

\section{Respondents' Demography}

Table 3.1 demonstrates general information of respondents, which it can be seen that respondents were predominantly female $(57.6 \%)$, aged in between $17-21$ years $(47.5 \%)$ and most of them were single status $(88.5 \%)$. Likewise, we also found that respondents were mainly from Vientiane capital (66.3\%), which their average monthly income was less than 1.000 .000 Kip (34.7\%), duration of use for Lao Telecom's service was less than six years (53.2\%) and they were students for the most part (67.9\%).

\section{Data Analysis}

For data analysis, we initially test a statistically significant difference between customers' loyalty with demographical variables (Namely gender, address, average monthly income and duration of use for Lao Telecom's service) by using statistical methods particularly: independent sample t-test and one way ANOVA. Similarly, we also apply multiple linear regression model to capture marginal effects of independent variables on dependent variable (Customers' loyalty) as well as the impacts of CSR on customers' loyalty in a telecommunication sector (service sector) in Lao PDR by utilizing SPSS version 26 and Stata version 16. 
Table 3.1 Respondents' Demography

\begin{tabular}{|c|c|c|c|}
\hline Demographical Variables & Description & Frequency & Percent $(\%)$ \\
\hline \multirow{2}{*}{ Gender } & Male & 181 & 42.4 \\
\hline & Female & 246 & 57.6 \\
\hline \multirow{6}{*}{ Age } & Less than 17 years & 2 & 0.5 \\
\hline & 17-21 years & 203 & 47.5 \\
\hline & $22-26$ years & 142 & 33.3 \\
\hline & $27-31$ years & 46 & 10.8 \\
\hline & $32-36$ years & 13 & 3 \\
\hline & More than 36 years & 21 & 4.9 \\
\hline \multirow{2}{*}{ Marital Status } & Single & 378 & 88.5 \\
\hline & Married & 49 & 11.5 \\
\hline \multirow{2}{*}{ Address } & Vientiane Capital & 283 & 66.3 \\
\hline & Other Province & 144 & 33.7 \\
\hline \multirow{7}{*}{ Occupation } & Student & 290 & 67.9 \\
\hline & Public Servant & 45 & 10.5 \\
\hline & State-Owned Enterprise Staff & 19 & 4.4 \\
\hline & Private Employee & 38 & 8.9 \\
\hline & Business Owner & 23 & 5.4 \\
\hline & International Organization Staff & 10 & 2.3 \\
\hline & Retired Public Servants/The Publics/Farmers & 2 & 0.5 \\
\hline \multirow{4}{*}{ Average Monthly Income } & Less than $1.000 .000 \mathrm{Kip}$ & 148 & 34.7 \\
\hline & $1.000 .000-1.500 .000 \mathrm{Kip}$ & 117 & 27.4 \\
\hline & $1.500 .001-2.000 .000 \mathrm{Kip}$ & 64 & 15 \\
\hline & More than 2.000.000 Kip & 98 & 23 \\
\hline \multirow{4}{*}{$\begin{array}{c}\text { Duration of Use (Lao } \\
\text { Telecom's Service) }\end{array}$} & Less than 6 years & 227 & 53.2 \\
\hline & $6-10$ years & 159 & 37.2 \\
\hline & 11-15 years & 20 & 4.7 \\
\hline & More than 15 years & 21 & 4.9 \\
\hline
\end{tabular}

Source: Author's calculation

\section{Empirical Findings and Discussions}

\section{Testable Outcomes of Compared Means}

Table 4.1 demonstrates the result of independent sample t-test to test, which the third hypothesis was constructed to investigate a significant difference between males' and females' attitude towards customers' loyalty. Our findings averred and revealed that there was a statistically significant difference between the mean for the male group $(\mathrm{Mean}=3.13, \mathrm{SD}=0.86)$ and female group $(\mathrm{Mean}=2.96, \mathrm{SD}=0.74)$ or for two different groups of people with a $1 \%$ significance level. Likewise, we also inferred that the male group was more likely to have more positive perception towards customers' loyalty than the female group. Hence, we can draw a conclusion that $\mathrm{H}_{3}$ is accepted.

Table 4.1 Result of Independent Sample T-test

\begin{tabular}{|c|c|c|c|c|c|c|}
\hline & \multirow{2}{*}{ Customers' Loyalty } & \multicolumn{2}{|c|}{$\begin{array}{c}\text { Levene's Test for } \\
\text { Equality of Variances }\end{array}$} & \multicolumn{3}{|c|}{ t-test for Equality of Means } \\
\hline & & $\mathbf{F}$ & Sig. & $\mathbf{t}$ & df & Sig. (2-tailed) \\
\hline \multirow{2}{*}{ Gender } & Equal variances assumed & \multirow{2}{*}{7.721} & \multirow{2}{*}{0.006} & $2.315^{* * *}$ & 425 & 0.021 \\
\hline & Equal variances not assumed & & & $2.263^{* * *}$ & 352.673 & 0.024 \\
\hline \multirow{2}{*}{ Address } & Equal variances assumed & \multirow{2}{*}{0.161} & \multirow{2}{*}{0.688} & $-0.348^{\mathrm{Ns}}$ & 425 & 0.728 \\
\hline & Equal variances not assumed & & & $-0.351^{\mathrm{Ns}}$ & 292.902 & 0.726 \\
\hline
\end{tabular}

Source: Author's calculation

Note: $* * *, * * *$ denotes a $10 \%, 5 \%$ and $1 \%$ significance level respectively

Similarly, the fourth hypothesis was also tested to examine a significant difference between the means for the group of people living in Vientiane capital and another province. The findings indicated that the mean for the group of people (respondents) living in Vientiane capital (Mean=3.02, $\mathrm{SD}=0.80$ ) found to be less than the mean 
for the group of people living in another province (Mean=3.05, $\mathrm{SD}=0.78$ ). However, our result confirmed there was not a statistically significant difference of the mean for two groups of respondents (Vientiane Capital and another province). Thus, we can conclude that $\mathrm{H}_{4}$ is not accepted.

This paper also applied one-way ANOVA to test whether there is a significant difference among the respondents' monthly income level (independent variable) and the respondents' duration of service use (independent variable) towards customers' loyalty (Group Mean). According to the outcome reported in table 4.2, we found a statistically significant difference among the respondents' duration of service use towards customers' loyal perception $(\mathrm{F}=4.138$, Sig. $=0.007)$ and the Post Hoc Tests showed a significant pairwise difference between (the duration of service use) less than 6 years and 6-10 years, which an average difference is 0.24 (6-10 years/less than 6 years), and between less than 6 years and more than 15 years with an average difference of 0.42 (more than 15 years/less than 6 years) at $1 \%$ significance level. Therefore, we can epitomize that $\mathrm{H}_{6}$ is accepted. Conversely, the findings also exhibited the absence of a statistically significant difference among average monthly income level of respondents. As a result, $\mathrm{H}_{5}$ is not accepted

Table 4.2 Result of One-Way ANOVA Test

\begin{tabular}{|c|c|c|c|c|c|c|}
\hline \multicolumn{2}{|c|}{ Customers' Loyalty } & Sum of Squares & df & Mean Square & $\mathbf{F}$ & Sig. \\
\hline \multirow{3}{*}{$\begin{array}{l}\text { Average Monthly } \\
\text { Income }\end{array}$} & Between Groups & 2.895 & 3 & 0.965 & \multirow{3}{*}{$1.538^{\mathrm{Ns}}$} & \multirow{3}{*}{0.204} \\
\hline & Within Groups & 265.393 & 423 & 0.627 & & \\
\hline & Total & 268.288 & 426 & & & \\
\hline \multirow{3}{*}{$\begin{array}{c}\text { Duration of Service } \\
\text { Use }\end{array}$} & Between Groups & 7.648 & 3 & 2.549 & \multirow{3}{*}{$4.138^{* * *}$} & \multirow{3}{*}{0.007} \\
\hline & Within Groups & 260.639 & 423 & 0.616 & & \\
\hline & Total & 268.288 & 426 & & & \\
\hline
\end{tabular}

Source: Author's calculation

Note: $*, * *, * * *$ denotes a $10 \%, 5 \%$ and $1 \%$ significance level respectively

\section{Multiple Linear Regression Model}

In order to examine the effects of corporate social responsibility (CSR) on customers' loyalty, we employed a multiple linear regression model to analyze the relationship and marginal effects of independent variables on dependent variable. Prior to running a multiple regression model, it is imperative to carefully check the issue of multicollinearity under the assumption that all the independent variables should not be highly correlated one another. In other words, the correlated value among independent variables is generally determined to be less than or equal to 0.6 for cross-sectional data/primary data. Based on correlation matrix method, we found that all the explanatory variables were not highly associated each other, the valid inference can be substantiated the absence of multicollinearity among exogenous variable.

Table 4.3 Results of Multiple Linear Regression Analysis

\begin{tabular}{|c|c|c|c|}
\hline Independent Variables & Coefficient & T-Statistic & P-value \\
\hline Ethical Responsibility & 0.0809 & $1.34^{\mathrm{Ns}}$ & 0.180 \\
\hline Legal Responsibility & 0.1189 & $1.68^{*}$ & 0.094 \\
\hline Philanthropic Responsibility & 0.2426 & $3.02^{* * *}$ & 0.003 \\
\hline Environmental Responsibility & 0.2166 & $3.44^{* * *}$ & 0.001 \\
\hline Constant (Intercept) & 0.5647 & $2.65^{* * *}$ & 0.008 \\
\hline F-Statistics & \multicolumn{3}{|c|}{36.76} \\
\hline Prob(F-Statistics) & \multicolumn{3}{|c|}{0.000} \\
\hline R-squared & \multicolumn{3}{|c|}{0.2584} \\
\hline Adjusted R-squared & \multicolumn{3}{|c|}{0.2514} \\
\hline Multicollinearity & \multicolumn{3}{|c|}{ No } \\
\hline Heteroskedasticity & \multicolumn{3}{|c|}{ No } \\
\hline
\end{tabular}

Source: Author's calculation

Note: $*, * *, * * *$ denotes a $10 \%, 5 \%$ and $1 \%$ significance level respectively

More accurately, we also checked to ensure whether the estimated model follows constant variance (Homoskedasticity) so as to obtain the best linear unbiased estimator (BLUE) from multiple regression model. According to the result of diagnostic checking, we found the estimated model was constant variance and the issue of heteroscedasticity does not exist. Empirical findings are reported in table 4.3, it can be concluded that the estimation of model fits very well with a set of observation/data with a significance level of $1 \%$ (FStatistics=36.76, Pro=0.000), while the coefficient of determination (R-squared=0.2584) reveals that the proportion of the variance for customers' loyalty (explanatory variable) can be explained by independent variables about $25.84 \%$. However, when considering all the factors/variables to be fixed/constant, it will influence in increase perception of customers' loyalty with the coefficient of $0.5647(56.47 \%)$. 
The customers' loyalty can be achieved through CSR activities, the effects of CSR on customers' loyalty will provide pivotal insights in improving and enhancing innovative marketing strategy, business performance, customers' satisfaction, service quality and penetration of broader customer targets. Based on the result depicted in table 4.3, we discovered that philanthropic responsibility has a statistical significance and positive effect on customers' loyalty for Lao Telecom company, an increase by 1 score (unit) of philanthropic responsibility conduces to rise customers' loyalty with the coefficient of 0.2426 score by significance level of $1 \%$. Consequently, $\mathrm{H}_{8}$ is accepted. Likewise, empirical evidence also asserted a positive influence and statistical significance of environmental responsibility on customers' loyalty. In other words, environmental responsibility aggrandizes by 1 score (unit) leads to rise by coefficient of 0.2166 for customers' loyalty, with a $1 \%$ significance level. Therefore, it can be concluded that $\mathrm{H}_{1}$ is accepted.

Furthermore, the estimated model depicted that legal responsibility is positively affected and statistically significant on customers' loyalty. That is to say, an increase by 1 score (unit) of this exogenous variable induces to rise by 0.1189 of coefficient $(0.1189$ score $)$ for customer's loyalty, with a significance level of $10 \%$, the outcome also substantiated a weak positive impact of relationship between legal responsibility and customers' loyalty. Thereupon, $\mathrm{H}_{7}$ is accepted. On the other hands, our empirical evidence found that ethical responsibility has a positive influence but statistical insignificance on explained variable in the estimated model. Hence, it is given a conclusion that $\mathrm{H}_{2}$ is not accepted.

Table 4.4 Summary of Testable Hypothesis

\begin{tabular}{|c|l|c|}
\hline Hypothesis & \multicolumn{1}{|c|}{ Relationship and Effect } & Result \\
\hline $\mathrm{H}_{1}$ & $\begin{array}{l}\text { Environmental responsibility is positively affected and statistically significant } \\
\text { on customers' loyalty }\end{array}$ & Supported \\
\hline $\mathrm{H}_{2}$ & $\begin{array}{l}\text { Ethical responsibility has a statistical significance and positive influence on } \\
\text { customers' loyalty }\end{array}$ & Not supported \\
\hline $\mathrm{H}_{3}$ & $\begin{array}{l}\text { There is a statistically significant difference between males' and females' } \\
\text { attitude towards customers' loyalty }\end{array}$ & Supported \\
\hline $\mathrm{H}_{4}$ & $\begin{array}{l}\text { There is a statistically significant difference between customers' perception } \\
\text { living in Vientiane capital and other province towards customers' loyalty }\end{array}$ & Not supported \\
\hline $\mathrm{H}_{5}$ & $\begin{array}{l}\text { There is a statistically significant difference among respondents' monthly } \\
\text { income level towards customers' loyalty }\end{array}$ & Not supported \\
\hline $\mathrm{H}_{6}$ & $\begin{array}{l}\text { There is a statistically significant difference among respondents' duration of } \\
\text { service use towards customers' loyalty }\end{array}$ & Supported \\
\hline $\mathrm{H}_{7}$ & $\begin{array}{l}\text { Legal responsibility is statistically significant and positive impact on } \\
\text { customers' loyalty }\end{array}$ & Supported \\
\hline $\mathrm{H}_{8}$ & $\begin{array}{l}\text { Philanthropic responsibility has a positive effect and statistical significance } \\
\text { on customers' loyalty }\end{array}$ & Supported \\
\hline
\end{tabular}

Source: Author's summary

Furthermore, the estimated model depicted that legal responsibility is positively affected and statistically significant on customers' loyalty. That is to say, an increase by 1 score (unit) of this exogenous variable induces to rise by 0.1189 of coefficient $(0.1189$ score $)$ for customer's loyalty, with a significance level of $10 \%$, the outcome also substantiated a weak positive impact of relationship between legal responsibility and customers' loyalty. Thereupon, $\mathrm{H}_{7}$ is accepted. On the other hands, our empirical evidence found that ethical responsibility has a positive influence but statistical insignificance on explained variable in the estimated model. Hence, it is given a conclusion that $\mathrm{H}_{2}$ is not accepted.

\section{Discussions and Implications}

Relevant literatures have confirmed that CSR has a positive effect on customers' loyalty by improving and enhancing company's brand image, customers' satisfactions, trustworthiness, behaviors, organization's longterm marketing strategy and so on, in order to become a strong market leader and snatch more market shares over competitor in the marketplace within same industry sectors. Based on hypothesis 1 , we enable to draw a conclusion that environmental responsibility demonstrates a positive impact on customers' loyalty and supported relevant previous studies (Moisescu \& Gică, 2020) and (Mohd Suki, 2015) and corroborated a strong influence on customers' loyalty (Liu et al., 2019). In other words, it helps to increase and better customers' loyalty through building good reputation and closer relationship with existing customers and penetrating vaster customer groups, namely Lao Telecom has supported "Good-Things- Project for Lao Society" in mitigating the plastic use, Garbage Collection Project for Clean City and other environmental activities. Unlike (Dimitriadis \& Zilakaki, 
2019) depicted a negative influence and not statistical significance of environmental accountability on customers' loyalty. Hence, it is epitomized that environmental responsibility plays a crucial role in fostering the long-term sustainable business performance and being a key to make customers' loyalty consciousness on service sector as well as Lao Telecom company, it can increase loyalty through corporate environmental activities, environmental stewardship involving in business operation and it is imperative for company/organization to take initiative in reducing the environmental degradation in order to achieve long-term business profit. On the other hands, for hypothesis 2 it revealed that ethical responsibility was associated in the same direction but not statistically significant on customers' loyalty, which is not in line with the past study (Arjoon \& Rambocas, 2011) demonstrating a positive impact and statistical significance of ethical responsibility on customers' loyalty.

Likewise, since the lack of empirical research as suggested and claimed by a previous literature (Arjoon \& Rambocas, 2011). To disentangle and complement those integral aspects, we also applied independent sample ttest method to test a significant difference between the mean for two group of people towards and employed oneway ANOVA to test a significant difference among group of people towards customers' loyal attitude as proposed in hypothesis 3,4,5 and 6. Based on the outcomes, we discovered new empirical evidence and argued that there was a statistically significant difference between the mean for the male group and female group (Hypothesis 3) and among respondents' duration of service use towards customers' loyalty (Hypothesis 6). In contrast, the mean for two group of people living in Vientiane capital and another province (Hypothesis 4) and the mean among respondents' monthly income level towards customers' loyalty was not statistically significant difference (Hypothesis 5). Consequently, the outcomes have provided new empirical evidences that have not investigated in previous literatures.

Based on the outcome of hypothesis 7 , we asserted that legal responsibility was a statistical significance and positive influence on customers' loyalty, which the result was consistent with past research (Arjoon \& Rambocas, 2011). To put it in another way, legal responsibility ponders as a pivotal bridge to build the reliable relationship with customers (Swaen \& Chumpitaz, 2008) and contributes to help in aggrandizing and advocating customers' loyalty through demonstration of good image and reputations to societal community and other stakeholders' involvement; companies/organizations should operate their business in line with the laws, rules and other relevant regulations, whilst (Islam et al., 2021) claimed that the it was essential for Telecom sectors to spend and invest in the ethical initiatives since customers in general prefer to support various organizations that have responsible ethnicity. In addition, (Zhang et al., 2015) supported the idea that any business operation with ethical ways can influence company's overall image and conduce to improve customers' loyalty and so on.

Furthermore, philanthropic responsibility plays a crucial role in enhancing company's good image, reputations, relationships with customers, successful business operation and increasing long-term business benefits as well as generating the sustainable revenue for organizations. As hypothesis 8 , it can be substantiated that philanthropic responsibility depicted a positive effect and statistical significance on customers' loyalty and this result has been corresponding with the preceding studies (Irshad et al., 2017), while (Chrisjatmiko \& Margareth, 2018) also supported the outcomes that philanthropic responsibility can accrue and better customers' loyalty through customers' purchase behavior, the pivotal strategies to improve this variable can be accomplished by creating various marketing programs in order to invite customers to contribute in social and community activities and charity programs should be established to penetrate the broader customer targets. Therefore, in order to accomplish for both the short term and long-term customers' loyalty as well as establish marketing competitive edges, Lao Telecom company should consider the factors in term of philanthropic responsibility at top priority by promoting social-community activities, helping the disadvantaged and adject people in remote area so as to improve their quality of life. Further, Lao Telecom should take philanthropic responsibility into consideration as a crucial weapon of contemporary marketing strategy to increase customers' loyalty that can improve business performance and make more comparative advantage over its competitors in the same industrial sectors and so forth.

\section{Conclusions}

Corporate social responsibility (CSR) has become an essential mainstream in research circles at present, especially for organizational business management and has been adopted as long-term strategic plans for company. It plays a crucial role in espousing sustainable business implementation, moderating the negative impact of environmental degradation and being an integral aspect in promoting social and community activities as well as enhancing the quality of life for local people. Stakeholders are expected that organizations/companies should undertake CSR activities as the top priority in order to mitigate their potential adverse effect caused from business operation. Numerous researchers strongly averred that CSR has established a positive effect on customers' loyalty and organizational performance in the long run. Nevertheless, very few empirical studies focused on the effects of CSR on customers' loyalty in a telecommunication sector (Service sector) and none of empirical evidence have investigated in case of Lao PDR. By realizing the significant notions of CSR activities 
that have an influence on customers' loyalty and the need to address those insoluble issues, this paper empirically investigates on the effects of CSR on customers' loyalty in Lao PDR by employing multiple linear regression model to identify the relationship between an explained variable and a set of regressor in the estimated model. To complement the results, we also applied independent sample t-test and one-way ANOVA method to test whether there is a statistically significant difference between/among the demographical variables towards customers' loyalty as proposed and suggested by (Arjoon \& Rambocas, 2011). We conducted an online survey through social medias and collected data from 427 samples from countrywide. Stata 16 were utilized to estimate the effects of CSR on customers' loyalty in Lao PDR.

Our empirical evidence based on independent sample t-test and one-way ANOVA asserted that there was a statistically significant difference between the mean for the male group and female group and among respondents' duration of service use towards customers' loyalty. On the contrary, the mean for two group of people living in Vientiane capital and another province and the mean among respondents' monthly income level towards customers' loyalty was not statistically significant difference. As a result, we have provided new empirical findings that have not investigated in previous literatures. The estimated outcome of multiple regression model can be epitomized that overall component of CSR activities was positively influenced and statistical significance on customers' loyalty. We confirmed a positive influence and statistical significance of philanthropic, environmental and ethical responsibility on customers' loyalty. That is to say, the CSR contributes to increase and improve customers' loyalty and promote long-term business development goals, and the estimated model found a weak positive effect of legal responsibility on customers' loyalty, whilst ethical responsibility was positively affected but statistical insignificance on customers' loyalty. Empirical findings also substantiated philanthropic responsibility is the most influential factor on customers' loyalty compared to the rest of explanatory variables with the higher coefficient of 0.2426 . Based on the results, this paper suggested that it is of essential prerequisite for Lao Telecom company to pay special attention on CSR actions in order to increase and enhance customers' loyalty through making the good image, reputation and positive attitude for customers. Lao Telecom company should also take the CSR activities into consideration as the innovative marketing strategy and core organizational management so as to achieve long-term business development goals and make potential positive impacts towards stakeholders as well as social community. Moreover, company should undertake to act as environmental stewardship and take initiatives to participate in corporate environmental activities in order to moderate the environmental degradation. It ought to realize the importance of investment in CSR activities, which these actions can build good reputation of company and enhance the reliable image, brand awareness, trustworthiness and satisfactions of customers that lead to increase customers' loyalty and so on.

However, there are some limitations in this research. First, we have investigated the effects of CSR on customers' loyalty by accentuating on a specific service sector as well as selecting Lao Telecom company as a case study in Lao PDR, which the outcomes may not be well-explained on the overall effects of CSR for other sectors and may suffer with the biased selection shortcomings of organization since there are still many telecommunication providers/companies in Lao PDR. Second, we merely focused on direct impacts of CSR on customers' loyalty by applying multiple linear regression model and did not take into consideration their indirect effects on explained variables in the estimated model through the specific mediators. Thirdly, this paper examined in the side of customers' attitude towards the CSR action of a company in a telecommunication sector, while the employees' perception on the CSR performance has not pondered in our research. Thereupon, the future research should consider the comparative study among disparate service sectors that not only in Lao PDR but also for other countries and other service sectors (such as financial, insurance, logistic sector etc.). Likewise, it would be interesting to investigate and test for trade and agricultural sector in order to compare the outcomes with the present studies and find innovative mechanisms of CSR actions. More fascinatingly, we suggest to consider different cultures, industries and longitudinal research in order to increase more impacts of findings. It is also important to test the multidimensional components of CSR towards customers' loyalty. In addition, the future direction should employ different method, specifically structural equation modeling (SEM) to capture direct and indirect effects of CSR components on customers' loyalty through pivotal mediators and we finally recommend to take into account the effects CSR on the outcomes of business performance, sustainable business development goals and long-term marketing strategies for both the same and divergent business sectors.

\section{References}

Arjoon, S., \& Rambocas, M. (2011). Ethics and Customer Loyalty: Some Insights into Online Retailing Services. International Journal of Business and Social Science, 2(14), 135-142. www.ijbssnet.com

Behringer, K. (2016). The Role Of CSR In Achieving Sustainable Development - Theoretical Approach Krisztina Szegedi , PhD , Associate Professor. 12(22), 10-25. https://doi.org/10.19044/esj.2016.v12n22p10

Castro-González, S., Bande, B., Fernández-Ferrín, P., \& Kimura, T. (2019). Corporate social responsibility and consumer advocacy behaviors: The importance of emotions and moral virtues. Journal of Cleaner 
Production, 231, 846-855. https://doi.org/10.1016/j.jclepro.2019.05.238

Chrisjatmiko, K., \& Margareth, D. (2018). the Impacts of Philanthropy Responsibility and Ethical Responsibility Toward Customer Purchase Behavior and Customer Loyalty. Jurnal Manajemen Dan Pemasaran Jasa, 10(1), 95. https://doi.org/10.25105/jmpj.v10i1.2272

Chung, K.-H., Yu, J.-E., Choi, M.-G., \& Shin, J.-I. (2015). The Effects of CSR on Customer Satisfaction and Loyalty in China: The Moderating Role of Corporate Image. Journal of Economics, Business and Management, 3(5), 542-547. https://doi.org/10.7763/joebm.2015.v3.243

Dahlsrud, A. (2008). How corporate social responsibility is defined: An analysis of 37 definitions. Corporate Social Responsibility and Environmental Management, 15(1), 1-13. https://doi.org/10.1002/csr.132

Dick, A. S., \& Basu, K. (1994). Customer loyalty: Toward an integrated conceptual framework. Journal of the Academy of Marketing Science, 22(2), 99-113. https://doi.org/10.1177/0092070394222001

Diehl, S., Terlutter, R., \& Mueller, B. (2016). Doing good matters to consumers: The effectiveness of humaneoriented CSR appeals in cross-cultural standardized advertising campaigns. International Journal of Advertising, 35(4), 730-757. https://doi.org/10.1080/02650487.2015.1077606

Dimitriadis, E., \& Zilakaki, E. (2019). The effect of corporate social responsibility on customer loyalty in mobile telephone companies. International Journal of Economics and Business Administration, 7(4), 433-450. https://doi.org/10.35808/ijeba/356

Galbreath, J., \& Shum, P. (2012). Do customer satisfaction and reputation mediate the CSR-FP link? Evidence from Australia. Australian Journal of Management, 37(2), 211-229. https://doi.org/10.1177/0312896211432941

Irshad, A., Rahim, A., Khan, M. F., \& Khan, M. M. (2017). THE IMPACT OF CORPORATE SOCIAL RESPONSIBILITY ON CUSTOMER SATISFACTION AND CUSTOMER LOYALTY, MODERATING EFFECT OF CORPORATE IMAGE (EVIDENCE FROM PAKISTAN) As the businesses are growing very fast today, there are different techniques and tools to make. City University Research Journal, AIC, 63-73.

Islam, T., Islam, R., Pitafi, A. H., Xiaobei, L., Rehmani, M., Irfan, M., \& Mubarak, M. S. (2021). The impact of corporate social responsibility on customer loyalty: The mediating role of corporate reputation, customer satisfaction, and trust. Sustainable Production and Consumption, 25, 123-135. https://doi.org/10.1016/j.spc.2020.07.019

Kim, S.-B., \& Kim, D.-Y. (2016). The impacts of corporate social responsibility, service quality, and transparency on relationship quality and customer loyalty in the hotel industry. Asian Journal of Sustainability and Social Responsibility, 1(1), 39-55. https://doi.org/10.1186/s41180-016-0004-1

Li, Y., Liu, B., \& Huan, T. C. (T C. ). (2019). Renewal or not? Consumer response to a renewed corporate social responsibility strategy: Evidence from the coffee shop industry. Tourism Management, 72(October 2018), 170-179. https://doi.org/10.1016/j.tourman.2018.10.031

Liu, M. T., Liu, Y., Mo, Z., Zhao, Z., \& Zhu, Z. (2019). How CSR influences customer behavioural loyalty in the Chinese hotel industry. Asia Pacific Journal of Marketing and Logistics, 32(1), 1-22. https://doi.org/10.1108/APJML-04-2018-0160

Maignan, I., Ferrell, O. C., \& Ferrell, L. (2005). A stakeholder model for implementing social responsibility in marketing. European Journal of Marketing, 39(9-10), 956-977. https://doi.org/10.1108/03090560510610662

Mohammed, A., \& Rashid, B. (2018). A conceptual model of corporate social responsibility dimensions, brand image, and customer satisfaction in Malaysian hotel industry. Kasetsart Journal of Social Sciences, 39(2), 358-364. https://doi.org/10.1016/j.kjss.2018.04.001

Mohd Suki, N. (2015). Customer environmental satisfaction and loyalty in the consumption of green products. International Journal of Sustainable Development and World Ecology, 22(4), 292-301. https://doi.org/10.1080/13504509.2015.1054328

Moisescu, O., \& Gică, O. (2020). The impact of environmental and social responsibility on customer loyalty: A Multigroup analysis among generations X and Y. International Journal of Environmental Research and Public Health, 17(18), 6466. https://doi.org/10.3390/ijerph17186466

Nyambura, M. R. (2018). Impact of Corporate Social Responsibility on Customer Loyalty in the Telecommunication Industry. Dissertation. http://erepo.usiu.ac.ke/handle/11732/4157

Ogetii Marita, N., \& Nyatichi Marita, N. (2019). Effect of Corporate Social Ethical Responsibility on Customer Loyalty: A Survey of Telecommunication Firms in Uasin Gishu County, Kenya. American Based Research Journal, 8(5), 2304-7151. http://www.abrj.org

Oliver, R. L. (1999). Whence Consumer Loyalty? Journal of Marketing, 63(4_suppl1), 33-44. https://doi.org/10.1177/00222429990634s105

Pérez, A., \& Bosque, I. R. del. (2014). Customer CSR expectations in the banking industry. International Journal of Bank Marketing, 32(3), 223-244. https://doi.org/10.1108/IJBM-09-2013-0095 
Raza, A., Saeed, A., Iqbal, M. K., Saeed, U., Sadiq, I., \& Faraz, N. A. (2020). Linking corporate social responsibility to customer loyalty through co-creation and customer company identification: Exploring sequential mediation mechanism. Sustainability (Switzerland), 12(6). https://doi.org/10.3390/su12062525

Servera-Francés, D., \& Piqueras-Tomás, L. (2019). The effects of corporate social responsibility on consumer loyalty through consumer perceived value. Economic Research-Ekonomska Istrazivanja , 32(1), 66-84. https://doi.org/10.1080/1331677X.2018.1547202

Slavova, I. (2017). Strategic Perspective of Corporate Social Responsibility. September.

Swaen, V., \& Chumpitaz, R. C. (2008). Impact of corporate social responsibility on consumer trust. Recherche et Applications en Marketing (English Edition), 23(4), 7-34. https://doi.org/10.1177/205157070802300402

Tellis, G. J. (1988). Advertising exposure, loyalty, and brand purchase: A two-stage model of choice. Journal of Marketing Research, 25(2), 134. https://doi.org/10.2307/3172645

Vilanova, M., Lozano, J. M., \& Arenas, D. (2008). Exploring the nature of the relationship between CSR and competitiveness. Globalization and the Good Corporation, 57-69. https://doi.org/10.1007/978-94-0070818-1 5

Wong, A., \& Sohal, A. (2003). Service quality and customer loyalty perspectives on two levels of retail relationships. Journal of Services Marketing, 17(5), 495-513. https://doi.org/10.1108/08876040310486285

Zhang, L., \& Mattila, A. S. (2015). An examination of corporate social responsibility and processing fluency in a service context. Journal of Services Marketing, 29(2), 103-111. https://doi.org/10.1108/jsm-11-2013-0307

Zhang, Y., Marquis, C., Filippov, S., Haasnoot, H., \& Van der Steen, M. (2015). The challenges and enhancing opportunities of global project management: Evidence from Chinese and Dutch cross-cultural project management. SSRN Electronic Journal. https://doi.org/10.2139/ssrn.2562376 